\title{
First World \\ and Third World after the Cold War
}

\section{Eric Hobsbawm}

Emeritus Professor of

Social and Economic History,

Birkbeck College,

University of London.

This exposition is about the United States and the Third World after the Cold War. However, this matter can only be understood in the light of the long history of the relations between the Western countries -the centre of the world system- and the periphery. This history began at the end of the 15 th century, when the Europeans, after a thousand years of defending themselves against invaders from Asia and Africa, embarked on their own era of world conquest.

In essence (at least for several centuries) this conquest was not based on greater wealth or overwhelming technical superiority, although scientific and technical progress in the most important regions of Western Europe was already more rapid and in some aspects more advanced than in any other part of the world. It was only in the 19th century, however, that the enormous gap between the per capita gross national product of the West and that of at least some of the non-Western countries became evident.

$\square$ This is an edited version of Professor Eric Hobsbawm's exposition at the seminar "El Mundo frente al Milenio", held on 25 November 1998, jointly organized by CENDA, ARCIS University, Revista Encuentro XXI and Editorial Grijalbo Mondadori and sponsored by ECLAC, among other institutions.
To begin with, the superiority of the conquerors lay in their maritime and military power, although the latter was still relatively limited. The only really large region conquered by the Europeans outside their own continent was America, where, for reasons that do not concern us here, the local empires were incapable of resisting the invasion. In Asia and Africa, in contrast, up to the 18th century the Europeans were only able to establish control over some ports, and even then only in areas where they were not confronting fairly large and effective States such as China and Japan. In short, in the first two and a half centuries European expansion was successful largely because local conditions did not prevent it. The relative weakness of the European empires was shown by their incapacity to control the independence movements which arose in America: neither in North America nor in Latin America were the European States able to resist these movements for long. ${ }^{1}$

\footnotetext{
1 The British quickly recognized these limitations. Thus, they did not make any serious attempt to reconquer the United States, even though they won a war in 1812-1813, and very soon after the Spanish colonies won their independence the British decided to refrain from direct military interventions, even in the River Plate region.
} 
However, the clear technical, economic and hence also military superiority of the centre over the periphery grew enormously in the 19th century, thanks to the so-called "tools of power" -gunboats, machine guns, artillery- and the construction of a worldwide support infrastructure for maritime supremacy. In the 19th century this infrastructure was almost entirely in the hands of the British, who were then the leading economic and world power.

Let us now take a brief look at the political implications of this situation. First, the States of the centre could easily and quickly reach the world of the periphery, but not the other way round. Great Britain could use gunboat diplomacy against China, but Chine could not do the same against Great Britain. In modern terms: the United States can reach Iraq, but Iraq cannot reach the United States. Second, in almost all armed conflicts between the First and Third Worlds, the former won the battles, generally with little difficulty. ${ }^{2}$

Third, the result was the political inferiority of the Third World States, large or small, compared with those of the First World, as is shown by the relations between the United States and Mexico and between Great Britain and China up to 1949. Up to the mid20th century, only one Third World State -Japan, which had successfully imitated the West- was able to escape from this inferiority and thus become part of the global power system.

Fourth, Third World States, or the Third World as a whole, could only offset this permanent inferiority with the support of one of the world powers. This was the function of the Soviet Union during the Cold War. The most extreme case is that of Cuba, which has survived as a Communist regime only 170 miles from Key West, thanks to the direct support of the Soviets. The end of the Cold War did away with this counterweight to the power of the developed world in general and the United States in particular.

\footnotetext{
2 This did not necessarily mean that the powers of the First World could win the whole war, however, unless it was a war against local governments. It was always hard and sometimes impossible to permanently defeat guerrilla movements in areas which favoured them, such as the Atlas Mountains in North Africa, Kurdistan or Afghanistan. The most intelligent of the imperial powers, Great Britain, gave up trying to occupy and administer such areas as the Northwest Frontier in India, and after the First World War it contented itself with controlling this area by periodically bombing it from the air, as in Kurdistan today.
}

This raises the question: why did the First World have to make so much use of its military and political superiority? Could it not have simply relied on the overwhelming advantages of its greater wealth and economic development, which increased spectacularly, especially during the Cold War? Well, it did indeed do this during the 19th century and much of the 20th century. We know that after the end, or withdrawal, of the old empires of the 16th to 18th centuries the sway of the First World increased, but the incentives to turn areas of the under-developed world into colonies went down during the 19th century, with a few notable exceptions. ${ }^{3}$ The example of Great Britain shows that the purely economic exploitation of the Third World did not require direct occupation, at any rate in the absence of another Western competitor. This was the "free trade colonialism" about which so much has been written. However, Great Britain naturally maintained a network of bases which were of strategic importance or were necessary in order to allow it to keep on controlling the international sea routes. At first sight, the present situation of the United States might seem similar, but I hope to show later that there are fundamental differences.

The resurgence of colonialism at the end of the 19th century -the so-called "new imperialism"- was due mainly to competition between rival Western States. It is worth recalling, however, that this was a period when, for economic and technical reasons, a number of raw materials and commodities which are mainly found in the Third World became vitally important and continue to be so: oil, non-ferrous metals, rubber, and various tropical foodstuffs. These goods caught the attention of Western businessmen and also, as some of them were of strategic importance, of governments too. As the history of the oil industry

\footnotetext{
3 The main exceptions were the United States, France, the Netherlands and British India. The United States was committed almost by definition to territorial expansion, which explains its conflict with its poor and backward neighbour to the south (the war with Mexico). Border disputes with the other developed country present in North America, Great Britain (in Canada), were settled peacefully by diplomatic means. For domestic policy reasons, France was committed to the conquest of Algeria, in the Southern Mediterranean, which was an area also used for European migration. The Netherlands and Great Britain (or rather the Dutch and British East India Companies) found, for reasons that do not concern us here, that after setting up territorial bases in India and Indonesia they had to expand those bases until they became great colonies.
} 
shows, however, the exploitation of this product did not necessarily call for colonial occupation. ${ }^{4}$

If we take a historical view, we can see that the new era of colonialism (of empires which insisted on direct occupation and administration) proved to be relatively short. Direct colonialism was a temporary fashion which only lasted a short time. Indeed, it can be contained within the lifetime of a single person: for example, that of Winston Churchill, who lived from 1874 to 1965 . Since the industrial revolution, capitalism has needed to create a world economy dominated by the capital accumulation centres, but this does not necessarily require a formal colonial system.

A recent development has brought in a new element in this respect, however. In the last quarter of the twentieth century, the centre of gravity of the increasingly globalized world economy has begun to shift to some extent from the original capitalist countries to the Third World, especially in manufacturing. Moreover, since the rise of the Japanese economy and the oil crisis of the 1970s, native capital accumulation outside Europe and North America has become much more important than before. ${ }^{5}$ This change was hastened by the enormous and growing difference in income between the First and Third World, which furthered the transfer of labour-intensive forms of production from high-wage areas to those of low wage levels (a well-known phenomenon in the case of Mexico). Likewise, this heightened the de-industrialization of the oldest industrial regions of the First World.

Thus, economically speaking, the international economy can no longer be considered as being divided simply between a First World concentrating most of the production and marketing of industrial goods and a Third World linked with the former as a producer of raw materials, although possessing an industrial sector based on the domestic market, as for example through import substitution (I will not refer to the more tightly closed economies of the socialist Second World which have now ceased to exist (like the former Soviet Union) or have changed their poli-

\footnotetext{
${ }^{4}$ The division of the world into colonies was confined to Africa and the Pacific. The Americas were hardly affected, nor were those parts of continental Asia which had not already been conquered, except for those which became the area of territorial expansion of Japan in East Asia.

${ }^{5}$ Before the 1970 s, even Japan -although a major military power since the beginning of the twentieth century- generated no more than $5 \%$ of the world industrial product.
}

cies (like China). Today, the Third World includes the fastest-growing industrial economies and the most export-oriented industry. As long ago as the late 1980s, over $37 \%$ of United States exports already came from the Third World, while almost $36 \%$ of its exports went to the latter.

For this reason, the economic superiority of the First World is no longer due to the fact that it is the most highly industrialized region or that it has the most "advanced" economy, except in one respect: that up to now it continues to almost monopolize scientific and technological research and development. ${ }^{6}$ Leaving aside this field, the First World's superiority lies in operating as an economic-financial conglomerate rather than a mere production plant. It houses the head offices of most of the great transnational corporations, which, with all their local branches and subsidiaries, account for a large part of the world economy. It has the faculty of laying down the framework for the world economy and its institutions, such as the World Bank and the International Monetary Fund, which it controls, and its immense wealth allows it to manage the greater part of world investment capital flows.

At the same time, however, this superiority makes the First World more dependent on what happens in the Third World. From the economic point of view, it is now much more important than before to have some degree of political control, especially in the case of the United States, which is the leading power in present-day capitalism. Until after the end of the Second World War, that country's economic development was based on its domestic market, and protecting its industry from foreign competition was traditionally much more important for it than free trade and export promotion. Although some specific branches of United States business and finance were deeply committed in one or another part of the Third World economy (the United Fruit Company, for example), the United States economy as a whole did not depend on its links with the Third World, unlike Great Britain, which had been the leading power in the nineteenth century.

This brings us to the specific matter that we will deal with here, which is the international position and policies of the United States after the Cold War.

\footnotetext{
${ }^{6}$ Even now, at the end of the present century, only a few Asians or Latin Americans have won a Nobel Prize in the sciences, and a number of those who have done so have worked or are working in Europe or the United States.
} 
The United States now occupies a position which has no precedent in history. It is the only real world power. In the nineteenth century, Great Britain occupied a position which was similar in many respects, as the only power with global interests, since the other countries, including the United States and Japan, only had regional interests. In politico-military terms, however, Great Britain was only one of several powers, although in one respect it outstripped them all until the twentieth century: the British Navy was bigger than all the others put together, although this only lasted until other powers, especially the United States and Japan, began to build up powerful naval forces themselves. But the present position of the United States is very much stronger, in both relative and absolute terms. There is no foreseeable possibility of any other power competing with its nuclear and aerial might. Since the collapse and disintegration of the Soviet Union, there is no other State or combination of States which could even dream of challenging it militarily.

For this reason, I think it is important to compare these two positions of dominance. It seems to me that there are three main differences between them, which are not unconnected with each other. Unlike Great Britain in the nineteenth century, the United States is an ideological empire (as Revolutionary France and the Soviet Union were in their day). Perhaps for this reason, the United States empire (unlike the British Empire) seeks to transform the world into its own image and likeness. In practice, this aspiration is superimposed on that of world political and military domination. The lust for control is political, not just economic: although in the present world situation free trade is in line with the United States's interests, that country's basic attitude has been to protect and foster United States capitalism through political action. Unlike Great Britain in the nineteenth century, the United States has a long history of military intervention abroad.

In the days of the Pax Britannica, things were different. As it was only a relatively small country, Great Britain could not allow itself the luxury of megalomania. Its European policy, for example, was based on the "balance of power". It did not aim to become the mightiest European power, but it did take care to ensure that the stronger powers were always at daggers drawn with each other, while Britain remained on the sidelines of the disputes. As successful pioneers in world industrialization, the British had enormous confidence in their economic system. ${ }^{7}$ They were also convinced that their political system was superior to all others, but they did not promote it as a general model. ${ }^{8}$ When nineteenth-century Britain did become a model for others, this was by example and not by design, as in the case of men's fashions and internationally popular sports, almost all of which were of British origin.

The Pax Britannica was thus very different from the Pax Americana, except that the British Navy, in the days when it ruled the waves, took the main responsibility for international maritime vigilance against such activities as piracy and (after its prohibition) the slave trade. Great Britain recognized its limitations. No British Foreign Secretary, not even Palmerston, would have referred to any part of the world whatever in the terms that Secretary of State Olney used with regard to the Western Hemisphere in 1895, when he declared that the United States was now practically all-powerful in that continent and that when it took up a matter its decisions had the force of law, because apart from all the other considerations, its unlimited resources and its position of isolation meant that it was in total control of the situation and was practically invulnerable to any or all other powers.

United States policy has therefore consistently been one of interventionism, first within the Western Hemisphere and subsequently all over the world. Great Britain had many colonies but no satellite States, except for what has been called "Britain's heyday in the Middle East", between 1918 and 1958. The United States has had very few colonies, but its aim has been to build up a system of satellite States. We may recall that the typical modus operandi of the United States intelligence service, the CIA, is to combine intelligence work proper with covert political actions.

Furthermore, as we have already seen, first within the Western Hemisphere and then worldwide, United States policy has been based on the acknow-

\footnotetext{
${ }^{7}$ So much so that they unilaterally adopted free trade and kept it up for almost a century, although no other State joined them in this: a highly beneficial policy for an economy based on trade with the Third World.

8 They considered that, regrettably but inevitably, the French and Americans would never be like them, while although the Russians would be better with stable laws and civil liberties they would still be quite un-British. As for the Third World, the British were convinced -mainly on the basis of their experience in governing India- that most of its inhabitants were permanently unfitted for the exercise of freedom.
} 
ledgement of its overwhelming power -both economic and technico-military- in its area of influence: a power that it has always been ready to use when necessary and which demands some degree of public acceptance and consideration on the part of other States. The older powers, accustomed to the conventions and practices of diplomacy, had not generally made such demands. The assumption -clearly implicit in the Helms-Burton Act- is that the United States is so indispensable to the rest of the world that it can use its national power to oblige other States to comply with United States policies even within the jurisdiction of their own territory.

During the Cold War, all this was justified on the grounds of the Soviet menace and accepted by the United States's allies and satellites as the price that had to be paid to keep Washington happy. ${ }^{9}$ But what is the situation today? The list of interventions since the end of the Cold War, when the Soviet threat no longer exists, is surprisingly long. It includes Panama in 1989, the Gulf War in 1991, Haiti in 1994, and various operations which had humanitarian or peacekeeping objectives but nevertheless involved the direct participation of United States forces, from Liberia and Somalia up to the Iraqui sector of Kurdistan and Bosnia. The most recent examples are the bombing raids on the Sudan and Afghanistan.

Indeed, as one United States author has noted, there is an ongoing conviction that military intervention is always likely to be the final response of the United States (Down, 1997, p. 202). Why is this so? Because other methods of asserting United States influence have come to be less effective, and because the real need for that country to continually assert its supremacy has increased. United States economic aid has drastically diminished, especially since the adoption of the Graham-Rudman-Hollings Act in the mid1980s, and this has weakened a traditional means of influencing other States. The success of economic sanctions, to which the United States has been strongly addicted, has gone down since the early 1970s, perhaps because the United States economy has lost relative weight or because such sanctions are no longer suitable for achieving particular objectives such as respect for human rights or controlling drug trafficking. Para-military and covert actions have had dubious results, although they have undoubtedly been very effective for harassing governments that the United States disapproves of and upsetting their functioning (Angola is a lamentable example of such cases). Furthermore, such actions are no longer so effective for overthrowing hostile governments as they were in the 1950s. In any case, they are not a weapon that can be used unilaterally, since they require the aid of a local ally (Schraeder, 1992, p. 149).

At the same time, the globalization of the economy has meant that the activities of transnational corporations (regardless of their country of origin) are now more dependent on the goodwill of the authorities of the country where they operate. The HelmsBurton Act seeks to bar from United States territory all foreigners whose economic activities in other parts of the world are not to the taste of the U.S. government. But this principle is applicable to all States. ${ }^{10}$ A country with such a long protectionist tradition as the United States has always been keenly aware of this political element in its foreign trade, which is very evident, for example, in the almost constant pressure by Washington on Japan for the latter to allow more United States imports to enter its territory. Naturally, the United States refrains from openly threatening States which it does not consider as adversaries or which are so weak as to be insignificant. It does consider it to be desirable, however, that everyone should be well aware that it can use what President Theodore Roosevelt called "the big stick".

Consequently, since the end of the 1980s the United States has worked out a systematic doctrine of what it calls "low-intensity conflict" suitable for the post-Cold War era. This is no longer based on the idea of preparation for a major war, but it does provide for the direct and if necessary armed intervention of Washington's allies or of the United States itself. Indeed, the end of the Cold War -that is to say,

\footnotetext{
${ }^{10}$ Without national authorization for aircraft to land there can be no international air traffic. The proposed merger between American Airlines and British Airways depends on a political decision between Washington and the European Union on the number of flights of these two airlines that are to be allowed to land at Heathrow Airport.
} 
the end of the danger of a world war- has loosened the brakes on the war machine. The Gulf War would not have been possible before this. President Bush himself proclaimed the new doctrine, declaring that the United States and its allies must build a common strategy to ensure stability in the developing world. And what are the threats to that stability? They are insurgency, terrorism and drug trafficking, he said. This means -in the words of Defense Secretary Cheney- that greater reliance must be placed on highly mobile forces prepared for immediate action and, in the jargon of the Pentagon, "with solid powerprojecting capabilities", that is to say, with capacity for massive long-distance military intervention. As a result, in recent years we have witnessed a number of highly visible examples of the United States capacity to intervene at a moment's notice anywhere in the world, no matter how far it may be from military bases on United States territory. We may recall in this respect the Gulf War, Somalia, Bosnia and, a couple of months ago, an exercise involving parachutists in one of the former Soviet republics of Central Asia.

At this point in our analysis we must ask ourselves: what is the capacity and what are the limits of this global military leadership? We will now make a few comments in this respect.

First of all, there is a growing gulf between the size and resources of the United States and those of the world dominated by it. I do not mean to say that the United States is in danger of what Professor Paul Kennedy of Yale has called "imperial overstretch": that is to say, imperial ambitions out of proportion to the available resources. Since the end of the Soviet Union there is no other military power that can compete with it, and as there is no danger of a major war at present, the United States can probably maintain its military supremacy without too much of an economic effort. However, although the United States currently accounts for no more than $5 \%$ of the world population yet generates 10 to $20 \%$ of world industrial output, the latter proportion is tending gradually to diminish.

Consequently, the United States is not really any more capable of "controlling" the world in the twenty-first century than the British were in the nineteenth century. Trying to maintain the political stability of the world is a reasonable objective for the United States, but imposing this through its military or economic power is beyond its possibilities. The most dangerous aspect is that despite its present pre- dominant position this country lacks both a diplomatic tradition and an objective awareness of its limitations.

Secondly, in spite of all its might, when acting alone the United States can only exert a relatively modest and limited amount of power. It needs allies abroad, because many of its military bases and much of its world infrastructure are on foreign territory. This is where there is a difference with the British hegemony in the nineteenth century, because the bases of the British maritime control system were British property: Gibraltar, the Falklands, Malta, Singapore, Hong Kong, and so forth. In 1973, even though it dominated the North Atlantic Treaty Organization (NATO), the United States did not have free use of its allies' air bases in peacetime. Moreover, United States domestic policy now places limits on military intervention, especially in most of the "lowintensity conflicts" envisaged in its late-twentieth century world strategy, because these conflicts often cannot be fought by remote control but involve ground troops. Bosnia and Chechenia are good examples of this. It is well known that United States public opinion always wants military victories, but only if they do not involve the loss of American lives. In order to overcome this problem it would be necessary to change both the structure of the United States military forces and American public opinion, and while this is not impossible, it has not yet occurred.

Thirdly, there are vast areas of the world -Africa, much of Asia, and even Eastern Europe- where we are currently witnessing the effective disintegration of States or a whole system of States. It is by no means clear how useful the new United States doctrine will be for dealing with "low-intensity conflicts" in such situations of instability. Clearly, in the event of war the First World would undoubtedly win all its battles against the Third World. But what about afterwards? Who would ensure stability? And where, in these unstable regions, would it be possible to find governments that were sympathetic to the West, docile, yet also capable of staying in power? When they look at what is happening in vast regions of Africa, some deeply discouraged observers wonder whether it would not be better to re-colonize those territories. This is no longer possible, however. The secret of the imperialism of the past -i.e., the passivity of the great majority of colonized peoples under their conquerors- has been lost. In any case, there is now such an abundance of highly effective and easily 
portable arms and explosives in the world that huge outlays of men and resources are needed to deal with quite small groups of armed activists: an outstanding case is that of Northern Ireland, where there are no more than 500 or so active guerrillas. In these circumstances, the cost-benefit calculations become highly unfavourable, and governments tend to be acutely aware of this in almost all cases where the territorial integrity of their countries is not directly threatened. It may be noted that in Africa the nonAfrican armies -even that of France, after forty years of interventionism- are withdrawing from the continent.

So, what does the military supremacy of the United States really count for? How far will it condition the behaviour of other countries?

I believe that the most effective use of the "big stick" is through the maintenance of the United States' virtual monopoly in the field of high-technology weapons. That country has a dual politico-military strategy: on the one hand it seeks to make its allies' military forces dependent on United States technology and supplies, without which they cannot operate, and on the other hand it seeks to prevent current or potential adversaries from producing high-technology weapons or obtaining them elsewhere. It may be assumed in this respect that the United States' relations with Iraq since the Gulf War mark the future pattern of its policy with regard to small and medium-sized States which refuse to submit to it. However, they also show the limits of Washington's strategy.

There remains another problem which is extremely serious both for the United States and for the First World as a whole: how to protect their economic superiority against the migration of the production centres of the global economy to the Third World. Although this problem is not yet a matter of immediate urgency for the First World, since China has not yet become a great world economic power, the politico-military hegemony of the United States is not capable of stopping this process. America does have two powerful weapons, however: its wealth, and the fact that it is indispensable for the functioning of the world economy. The aim of the old centres of economic power in general and of the United States in particular is none other than to keep the world economy under their control. Universal free trade has always been the favoured programme of the economies that dominate world trade, as it now is of the United States.
However, we must always bear in mind that the rise of the newly industrialized countries, and especially the economic miracles of the "Asian Tigers", have been based on rejection of the neoliberal freemarket theology. As these newly industrialized economies, which are relatively weak and almost always heavily indebted, become incorporated into the global economy they become vulnerable to the pressures of the International Monetary Fund and other centres of international credit, in which the political weight of the United States is predominant. In South Korea -under the pressure and with the aid of the United States- the Fund wants to impose neoliberalism (including the right of foreign firms to purchase control of Korean enterprises) on an economy which has achieved in thirty years the most rapid transformation ever known from a poor and backward agricultural country into one of the most important industrial economies in the world, with an almost unprecedented rise in the standard of living and political progress from a developmentalist military dictatorship to something close to democracy. The aim behind this pressure is no doubt to break any economic models which run counter to global neoliberalism and any States or groups which stand in the way of such global restructuring.

Is the economic strength of the United States sufficient to maintain this control? The situation cannot last for ever: in the long run the predominance of the United States cannot survive the future growth of the global economy, that is to say, the relative decline in the weight of the United States economy. Up to just a short while ago, I would have said that we are still solidly in the era of free trade, and moreover we are not confronting only the politico-economic power of the United States, but also a powerful orthodox ideology. The most dangerous legacy of the 1970s and 1980s has been the conversion of most economists to the theology of absolute neoliberalism. ${ }^{11}$ The consequences of economic programmes of this nature have already proved to be fatal in the regions where "real socialism" previously prevailed, and they have had results which can be described at the very least as dubious in the case of Mexico. The developing countries, including those of Latin America, are living under

\footnotetext{
11 This is clear from the nominations for the Nobel Prizes in economics since 1975 .
} 
both the politico-economic pressure of Washington and the ideological pressure of an intellectual consensus devoid of both historical and social realism.

In the last few months, however, there have been significant changes even in the preferences of those responsible for awarding the Nobel Prize. The heyday of consensus among economists, of the utopia of capitalism without any problems, of neoliberal fundamentalism, is coming to an end, and it has been discovered that the future of the world does not necessarily lie in the universalization of the model based on United States capitalism.

It is therefore much clearer now than it was before that there are limits to the United States' hegemony over the world economy, just as there are limits to its military and political hegemony.

\section{Bibliography}

Down, R. (1997): The impact of the end of the cold war on interamerican relations: The search for paradigm and principle, Journal of Interamerican Studies and World Affairs, vol. 39, No. 2, Beverly Hills, Cali- fornia, University of Miami Center for Advanced International Studies.

Schraeder, W. P. (1992): Intervention in the 1990s: US Foreign Policy in the Third World, 2nd. edition. 